\title{
Women Entrepreneurial Skills of Self Help Groups for Sustainable Development in Tirunelveli District
}

\author{
R. Selvakumar, S. Karthik
}

\begin{abstract}
The major problem of unemployment has brought into focus the importance of small scale, agro and rural industries as well as the development of entrepreneurship in the related fields. Women in our country are playing an equally important role through development of their resource-fullness and their skills. Entrepreneurial skill of women shows the way for the empowerment of women and social justice. It facilitates the women to become economic independence, self reliance, political, social and legal awareness, self-confidence and positive attitude among the women community. The main aim of this study is to identify the general profile of Self Help Groups in Tirunelveli district and analyze the level of imperative entrepreneurial skills of members in Self Help Groups. For this, the opinion of Animators has collected from each Self Help Group towards the entrepreneurial skills of members acquired through the Group. This study shows the fact that the self confidence level and leadership quality level of members have increased after joining SHGs
\end{abstract}

Key words: Women entrepreneur, Animators, Skills, SHGs

\section{INTRODUCTION}

The poverty and unemployment are the twin and mounting problems that are common in the Third World countries. The mounting problems of unemployment have brought into focus the importance of small scale, agro and rural industries as well as the development of entrepreneurship in the related fields. A woman is never viewed as a person having her own rights but always as some one's daughter, wife and mother. In each and every movement of woman is dominated by man. Women in our country play an equally important role through development of their resource-fullness and their skills. At the outset the Animators are playing very important role for the smooth functioning of SHGs. They are keenly observing and motivating the members for their overall development. They are conducting the group activities periodically and allow the members to take participate in it. For this, they need to get support from the NGO and Governmental organization for the growth of the SHGs. This study deals with the level of entrepreneurial skills of members like innovativeness, planning, decision making,

Revised Manuscript Received on December 16, 2019

R. Selvakumar, Associate Professor, Department of Commerce, Kalasalingam Academy of Research and Education, Krishnan Koil, Virudhunagar Dist, Tamilnadu

E-mail id: selvakumar.r@klu.ac.in

S. Karthik, Associate Professor, Department of Commerce, Kalasalingam Academy of Research and Education Krishnan Koil, Virudhunagar Dist, Tamilnadu

E-mail id: karthik.s@klu.ac.in risk taking, leadership, cosmopolitan outlook, goal achievement and so on.

\section{RESEARCH PROBLEM}

Integration of women development and their empowerment are inevitable for the development of any country. The role of women in economic and social activities of a country was emphasized by the World Conference on Agrarian Reforms and Rural Development in 1979. Different plans and policies of the past years as well as the Constitution have laid stress on women empowerment. Entrepreneurial skill of women paves way for the empowerment of women and social justice. It creates economic independence, self reliance, political, social and legal awareness, self-confidence and positive attitude among women. It enables women to face any situation and to participate in the developmental activities of the nation. Animators are the guiders, motivators and conductors of Groups and business activities. Since the Animators are the role model for the members in SHGs, how far they are extending support to each and every member of SHGs in their individual development especially entrepreneurial activities. Hence, the researcher made an attempt to analyze the level of entrepreneurial behavior among the members of Self Help Groups in the selected district.

\section{REVIEW OF LITERATURE}

Praveen Kumar (2015) $^{\mathbf{1}}$ has inferred that empowered economy can be achieved only through attainment of social and economic development of women. He has pointed out that different issues and challenges of women can be solved through women entrepreneurship. It helps to develop economy also.

Kumar, p., (2015) ${ }^{\mathbf{2}}$ has stated that continuous support in terms of finance and psychological motivation are needed for the successful women entrepreneurs. He was also insisted that various awareness program should be conducted in the area of business.

Kavita Sangolagi1, Mallikarjun Alagawadi $(2016)^{3}$ have highlighted that to eliminate the problems of poverty and unemployment, greater attention should be given on Women empowerment and Women entrepreneurship. They found that support from family members are decisive for creating talent. In their study, they inferred that the various opportunities for growth and challenges faced by women entrepreneurs of today. 
NehaTiwari $(\mathbf{2 0 1 7})^{4}$, has made an attempt to bring out the main concept, general outline and dynamics of women entrepreneurs in India. Women entrepreneurs in India are having heterogeneous character in terms of their demographic factors. They are bald-faced with gender and initiative challenges in operating their business ventures. He pointed out few states were lesser concentration in the entrepreneurial activity like Tamil Nadu, Kerala, Andhra Pradesh, West Bengal and Maharashtra etc., Hence, so much weightage should be given and make new policies which will enhance the positive environment for women entrepreneurs in India.

\section{OBJECTIVES OF THE STUDY}

* To know about demographic profile of Women Self Help Groups in Tirunelveli District.

* To Study and analyze the imperative of selected entrepreneurial skills of women members in Self Help Groups.

\section{METHODOLOGY USED FOR THE STUDY}

\subsection{Sources of Data}

The study has used both primary and secondary data. Primary data have collected through interview schedule from the selected respondents. Secondary data have collected from various books, websites and other online resources.

\section{2 Sampling Design}

For the study purpose, Tirunelveli district has selected and having 19 blocks. There are more than 15,000 Self Help Groups in Tirunelveli district. Among these groups, 1050 groups are only doing business activities. By adopting simple randam sampling interview method, $10 \%$ of SHGs (105 SHGs) have selected from each block by using lottery method.

\subsection{Hypothesis of the study}

* There is no significant difference between the responses of Animators towards the self confidence level of members.

* There is no significant difference between the responses of Animators towards leadership skills level of members.

\subsection{Framework of Analysis:}

In this study, the researcher has used percentage analysis for finding out demographic profile and Sign test has used to analyze skills relating to self confidence, leadership quality and cosmopolitan outlook at different situations.

\section{RESULTS AND DISCUSSIONS}

The following are analysis and interpretation of the study.

\subsection{DEMOGRAPHIC PROFILE OF SELF HELP GROUPS IN TIRUNELVELI DISTRICT}

Table 6.1 shows that demographic profile of 105 SHG's members. Majority of the SHGs $\mathbf{5 1 . 4 3}$ per cent are formed and they are functioning in rural area. It is inferred that $\mathbf{5 5 . 2 4}$ per cent of SHGs have the size of members ranging from 10 to 15 . It is identified that $\mathbf{5 4 . 2 9}$ per cent of SHGs have selected the members on the basis of poverty. It is showed that majority illiterate people (95.24\%). Nearly one-third of the SHGs have experience up to 3 Years. Most of the SHGs 40 per cent are operating under the guidance of Non-Governmental Organization.

Table 6.1Demographic Profile Of Self Help Groups In Tirunelveli District

\begin{tabular}{|c|c|c|c|}
\hline \multicolumn{2}{|l|}{ Particulars } & \multirow{2}{*}{$\begin{array}{l}\text { No of } \\
\text { Respondents } \\
54\end{array}$} & \multirow{2}{*}{$\begin{array}{l}\begin{array}{l}\text { Percentage } \\
\text { to Total }\end{array} \\
\mathbf{5 1 . 4 3} \\
\end{array}$} \\
\hline Area of & Rural & & \\
\hline $\begin{array}{c}\text { Resident of } \\
\text { Groups }\end{array}$ & Urban & 51 & 48.57 \\
\hline \multirow{3}{*}{$\begin{array}{c}\text { Size of the } \\
\text { SHGs }\end{array}$} & $10-15$ & 58 & 55.24 \\
\hline & $16-19$ & 23 & 21.9 \\
\hline & 20 & 24 & 22.86 \\
\hline \multirow{5}{*}{$\begin{array}{c}\text { Selection of } \\
\text { Members in } \\
\text { SHGs }\end{array}$} & Same Locality & 30 & 28.57 \\
\hline & Poverty & 57 & 54.29 \\
\hline & Profession & 3 & 2.86 \\
\hline & Caste & 1 & 0.95 \\
\hline & Loyalty & 14 & 13.33 \\
\hline \multirow{2}{*}{$\begin{array}{c}\text { Literacy } \\
\text { Level of } \\
\text { SHGs } \\
\end{array}$} & Literate & 5 & 4.76 \\
\hline & Illiterate & 100 & 95.24 \\
\hline \multirow{4}{*}{$\begin{array}{c}\text { Experience } \\
\text { of SHGs }\end{array}$} & Up to 3 Years & 36 & 34.29 \\
\hline & $3-6$ Years & 33 & 31.43 \\
\hline & $6-9$ Years & 18 & 17.14 \\
\hline & Above 9 Years & 18 & 17.14 \\
\hline \multirow[b]{4}{*}{$\begin{array}{c}\text { Nature of } \\
\text { SHGs }\end{array}$} & $\begin{array}{l}\text { SHG Directly } \\
\text { Operating }\end{array}$ & 31 & 29.53 \\
\hline & $\begin{array}{l}\text { NGO } \\
\text { Facilitate }\end{array}$ & 42 & 40 \\
\hline & $\begin{array}{l}\text { NGO } \\
\text { Intermediate }\end{array}$ & 9 & 8.57 \\
\hline & $\begin{array}{l}\text { Self Help } \\
\text { Promoting } \\
\text { Institution }\end{array}$ & 23 & 21.9 \\
\hline
\end{tabular}

Source : Primary Data

\subsection{OPINION OF ANIMATORS TOWARDS ENTREPRENEURIAL SKILLS OF SELF HELP GROUP MEMBERS}

The researcher has made an analysis to ascertain the opinion about the levels of entrepreneurial skills of members from the Animators of each SHG. The good and positive entrepreneurial behavior is purely based on the entrepreneurial skills acquired by the members after joining SHGs. The entrepreneurial skills include innovativeness, planning, decision making, risk taking, goal achievement, leadership and self confidence. These skills have been providing to the members of SHGs through proper entrepreneurial oriented training programmes. Therefore, it is greater need to analyze the level of entrepreneurial skills of members among SHGs for becoming successful entrepreneurs in the study area.

\subsubsection{INNOVATIVE IDEAS GIVEN BY MEMBERS OF SHGS}

Innovation is the basic element of entrepreneurship. The innovative ideas such as new methods of production, new methods of marketing, new technology, new methods of selling and the like may be given by the members to the business. These details are asked from the Animators of each SHG and displayed in Table 6.2 
Table 6.2 Innovative Ideas Given by Members of SHGs

\begin{tabular}{|c|c|c|}
\hline $\begin{array}{l}\text { Innovative } \\
\text { Ideas }\end{array}$ & $\begin{array}{l}\text { No. of } \\
\text { Respondent }\end{array}$ & $\begin{array}{l}\text { Percentage to } \\
\text { Total }\end{array}$ \\
\hline Given & 74 & 70.48 \\
\hline Not Given & 31 & 29.52 \\
\hline Total & 105 & 100.00 \\
\hline
\end{tabular}

Source: Primary Data.

Table 6.2 clearly reveals that out of 105 Animators of SHGs, 70.48 per cent of them have opined that their group members have given one or more innovative ideas related to business activities and the remaining $\mathbf{2 9 . 5 2}$ per cent have replied that members have not given any innovative ideas to the business activities. It is understood that majority $\mathbf{7 0 . 4 8 \% )}$ of the Animators have expressed that their members have given innovative ideas to business activities.

\subsubsection{NATURE OF INNOVATIVE IDEAS GIVEN BY MEMBERS}

The researcher has analyzed the types of innovative ideas given by the members. It is presented in Table 6.3.

Table 6.3 Nature of Innovative Ideas Given by Members

\begin{tabular}{|l|l|l|l|}
\hline $\begin{array}{l}\text { Nature of } \\
\text { Innovative } \\
\text { Ideas }\end{array}$ & $\begin{array}{l}\text { No. of } \\
\text { Response } \\
\text { s }\end{array}$ & $\begin{array}{l}\text { Total No. of } \\
\text { Respondent } \\
\text { s }\end{array}$ & $\begin{array}{l}\text { Percentag } \\
\text { e to Total }\end{array}$ \\
\hline $\begin{array}{l}\text { Adopted new } \\
\text { methods of } \\
\text { production }\end{array}$ & 55 & 74 & $\mathbf{7 4 . 3 2}$ \\
\hline $\begin{array}{l}\text { Created new } \\
\text { methods of } \\
\text { marketing }\end{array}$ & 29 & 74 & 39.19 \\
\hline $\begin{array}{l}\text { Adopted new } \\
\text { technology }\end{array}$ & 34 & 74 & 45.95 \\
\hline $\begin{array}{l}\text { Introduced new } \\
\text { line of products }\end{array}$ & 19 & 74 & 25.68 \\
\hline $\begin{array}{l}\text { Adopted new } \\
\text { methods of } \\
\text { selling }\end{array}$ & 30 & 74 & 40.54 \\
\hline
\end{tabular}

Source: Primary Data.

Table 6.3 reveals that out of $\mathbf{7 4}$ Animators, $\mathbf{7 4 . 3 2}$ per cent opined that their members have implemented new methods of production in their business, $\mathbf{4 5 . 9 5}$ per cent replied that members have adopted new technology, $\mathbf{4 0 . 5 4}$ per cent felt that members have followed new methods of selling in their business activities, 39.19 per cent answered that members have created new methods of marketing and the remaining 25.68 per cent said that members have introduced new line of products. It is inferred that majority $\mathbf{( 7 4 . 3 2 \% )}$ of the Animators have responded that members have adopted new methods of production in their business.

\subsubsection{CONTRIBUTION OF MEMBERS IN PLANNING}

The planning activities may be related to preparation of budget for business, finance, marketing, sales, production and the like. This is presented in Table 6.4.

Table 6.4 Contribution of Members in Planning

\begin{tabular}{|l|l|l|}
\hline Contributions & Yes & No \\
\hline $\begin{array}{l}\text { Preparation of budget for } \\
\text { business }\end{array}$ & $46(43.81 \%)$ & $59(56.19 \%)$ \\
\hline Financial oriented & $43(40.95 \%)$ & $62(59.05 \%)$ \\
\hline Marketing oriented & $36(34.29 \%)$ & $69(65.71 \%)$ \\
\hline Technology oriented & $31(29.52 \%)$ & $74(70.48 \%)$ \\
\hline Production oriented & $50(47.62 \%)$ & $55(52.38 \%)$ \\
\hline
\end{tabular}

\begin{tabular}{|l|ll|l|}
\hline Sales oriented & 52 & $(49.52 \%)$ & $53(50.48 \%)$ \\
\hline $\begin{array}{l}\text { Plans related to group } \\
\text { activities }\end{array}$ & $\mathbf{7 3}$ & $\mathbf{( 6 9 . 5 2 \% )}$ & $32(30.48 \%)$ \\
\hline Investment Oriented & $34(32.38 \%)$ & $71(67.62 \%)$ \\
\hline Social Service related & $08(7.62 \%)$ & $97(92.38 \%)$ \\
\hline
\end{tabular}

Source: Primary Data.

Table 6.4 points out that out of $\mathbf{1 0 5}$ Animators, $\mathbf{6 9 . 5 2}$ per cent expressed that their members have planned related to group activities, 49.52 per cent shared their opinion that their members have contributed in sales oriented plans, 47.62 per cent of them told that members have actively participated in production related plans, $\mathbf{4 3 . 8 1}$ per cent of them opined that their members have contributed in preparing a budget for business, $\mathbf{4 0 . 9 5}$ per cent of them shared that members helped in making financial oriented plans and so on. It is concluded that majority (69.52\%) of Animators have opined that group members have actively participated in group related plans.

\subsubsection{OPINION ABOUT GOAL ACHIEVEMENT OF MEMBERS IN THE GROUP}

The researcher has made an analysis to identify goals fixed and achieved by the members in group business as well as individual business and personal life. The goals may be related to life, intention to earn money, support financially to their dependents, provide employment to others, rendering service to the society and becoming a good entrepreneur. This is narrated in Table 6.5.

Table 6.5Opinion about Goal Achievement of Members in the Group

\begin{tabular}{|l|l|l|}
\hline Achievement of goals & Yes & No \\
\hline Life goal & 79 (75.24\%) & $\begin{array}{l}26 \\
(24.76 \%)\end{array}$ \\
\hline Intention to earn money & $78 \quad(74.29 \%)$ & $\begin{array}{l}27 \\
(25.71 \%)\end{array}$ \\
\hline $\begin{array}{l}\text { Support financially to } \\
\text { their dependents }\end{array}$ & $71 \quad(67.62 \%)$ & $\begin{array}{l}34 \\
(32.38 \%)\end{array}$ \\
\hline $\begin{array}{l}\text { Provide employment to } \\
\text { others }\end{array}$ & $65 \quad(61.90 \%)$ & $\begin{array}{l}40 \\
(38.10 \%)\end{array}$ \\
\hline $\begin{array}{l}\text { Rendering service to } \\
\text { society }\end{array}$ & $42 \quad(40.00 \%)$ & $\begin{array}{l}63 \\
(60.00 \%)\end{array}$ \\
\hline $\begin{array}{l}\text { Becoming a good } \\
\text { entrepreneur }\end{array}$ & $62(59.05 \%)$ & $\begin{array}{l}43 \\
(40.95 \%)\end{array}$ \\
\hline Group Goals & $51 \quad(48.57 \%)$ & $\begin{array}{l}54 \\
(51.43 \%)\end{array}$ \\
\hline
\end{tabular}

Source: Primary Data.

It is clear from Table 6.5 that out of $\mathbf{1 0 5}$ Animators interviewed, $\mathbf{7 5 . 2 4}$ per cent of them feel that their members have fixed goals to lead a successful life, 74.29 per cent of them opined that members are having intention to earn money, 67.62 per cent of them answered that members have been supporting financially to their dependents, $\mathbf{6 1 . 9 0}$ per cent of them replied that members have been providing employment to others, $\mathbf{5 9 . 0 5}$ per cent of them answered that members are having a aim to become a good entrepreneur, 48.57 per cent of them opined that members have interested in achieving group goals and the rest $\mathbf{4 0 . 0 0}$ per cent of them said that members have been rendering service to the society. It is concluded that majority (75.24\%) of the Animators have replied that members have fixed goals to lead a successful life.

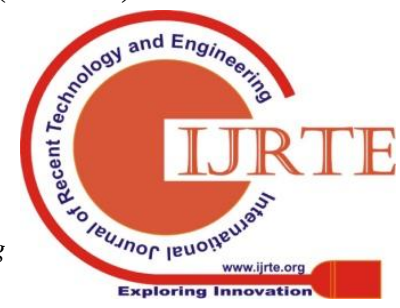




\subsubsection{RISK TAKEN BY MEMBERS IN GROUP OR INDIVIDUAL BUSINESS}

It is the important element involved in business activities. In order to know the risk bearing capacity of the members, this analysis is made and narrated in Table 6.6.

\section{TABLE 6.6}

Risk taken by Members in Group or Individual Business

\begin{tabular}{|l|l|l|}
\hline $\begin{array}{l}\text { Facing of } \\
\text { risk }\end{array}$ & $\begin{array}{l}\text { No. of } \\
\text { Respondents }\end{array}$ & Percentage to Total \\
\hline Faced & 38 & 36.19 \\
Not Faced & 67 & 63.81 \\
\cline { 2 - 3 } Total & $\mathbf{1 0 5}$ & $\mathbf{1 0 0 . 0 0}$ \\
\hline
\end{tabular}

Source: Primary Data.

It is understood from Table 6.6 that out of $\mathbf{1 0 5}$ Animators investigated, 36.19 per cent of them expressed that the members have taken risks involved in business and the rest 63.81 per cent of them opined that members have not met any type of risk in business It is inferred that majority (63.81) of the Animators have opined that the members have not taken any type of risks involved in business because of fear about loss.

\subsubsection{NATURE OF RISKS FACED BY MEMBERS}

The risks may arise related to Finance, Production, Technology, Investment, Marketing and Sales oriented. These details are furnished in Table 6.7

\section{TABLE 6.7}

Nature of Risks Faced by Members

\begin{tabular}{|l|l|l|l|}
\hline $\begin{array}{l}\text { Nature of } \\
\text { Risks Faced }\end{array}$ & $\begin{array}{l}\text { No. of } \\
\text { Response } \\
\text { s }\end{array}$ & $\begin{array}{l}\text { Total No. of } \\
\text { Respondent } \\
\text { s }\end{array}$ & $\begin{array}{l}\text { Percentag } \\
\text { e to Total }\end{array}$ \\
\hline $\begin{array}{l}\text { Financially } \\
\text { Oriented } \\
\text { Production } \\
\text { Oriented } \\
\text { Technology } \\
\begin{array}{l}\text { Oriented } \\
\text { Investment } \\
\text { Oriented } \\
\text { Marketing and } \\
\text { Sales Oriented }\end{array}\end{array}$ & 12 & 38 & 31.58 \\
\hline
\end{tabular}

\section{Source: Primary Data.}

Table 6.7 reveals that $\mathbf{7 8}$ responses were collected from $\mathbf{3 8}$ Animators of SHGs. Out of $\mathbf{3 8}$ Animators, $\mathbf{5 7 . 8 9}$ per cent of them answered that members have faced both production oriented risks, Technology Oriented risks . 42.11 per cent of them replied - members have taken marketing and sales oriented risks, $\mathbf{3 1 . 5 8}$ per cent of them opined that group members have met financial oriented risks and $\mathbf{1 5 . 7 9}$ per cent of them opined that investment oriented risks have experienced by members. It is crystal clear that majority (57.89) of the Animators have opined that the members have faced production and technology oriented risks.

\subsubsection{DECISION TAKEN BY MEMBERS IN GROUP ACTIVITIES}

Group is exposed of various problems especially in its initial stages to be a stable one. In order to identify the decision making skills possessed by members to solve problems in group activities, this analysis is made and presented in Table 6.8 .

TABLE 6.8

Decision taken by Members in Group Activities

\begin{tabular}{|l|l|l|}
$\begin{array}{l}\text { Taking of } \\
\text { Decisions }\end{array}$ & $\begin{array}{l}\text { No. of } \\
\text { Respondents }\end{array}$ & $\begin{array}{l}\text { Percentage to } \\
\text { Total }\end{array}$ \\
\hline Taken & 90 & 85.71 \\
Not taken & 15 & 14.29 \\
\cline { 2 - 3 } & $\mathbf{1 0 5}$ & $\mathbf{1 0 0 . 0 0}$ \\
\hline
\end{tabular}

Source: Primary Data.

From the above analysis it is pointed out that whether the members have taken any decision related to group activities or not. Out of 105 Animators investigated, 85.71 per cent of them replied that the members have taken one or more decisions in group activities and the rest $\mathbf{1 4 . 2 9}$ per cent of them expressed that members have not taken decisions in group activities. It is clear that majority $(\mathbf{8 5 . 7 1 )}$ of the group members have taken one or more decisions in group activities.

\subsubsection{NATURE OF DECISION TAKEN BY MEMBERS IN GROUP /INDIVIDUAL BUSINESS}

Problems are inherent in business irrespective of the size of business. The problems may be related to Competition, Finance, Technology, day-to-day life of Business, Marketing, sales Oriented and so on. So that members are in a position to take decisions to overcome such business problems. These details are presented in Table 6.9.

TABLE6.9

Nature of Decision Taken by Members in Group or Individual Business

\begin{tabular}{|c|c|c|c|}
\hline $\begin{array}{l}\text { Nature of } \\
\text { decisions in } \\
\text { business }\end{array}$ & $\begin{array}{l}\text { No. of } \\
\text { Respon } \\
\text { ses }\end{array}$ & $\begin{array}{l}\text { Total No. } \\
\text { of } \\
\text { Responde } \\
\text { nts }\end{array}$ & $\begin{array}{l}\text { Percentag } \\
\text { e to Total }\end{array}$ \\
\hline $\begin{array}{l}\text { Overcome } \\
\text { competition }\end{array}$ & 29 & 90 & 32.22 \\
\hline $\begin{array}{l}\text { Financial } \\
\text { Oriented problems }\end{array}$ & 34 & 90 & 37.78 \\
\hline $\begin{array}{l}\text { Technological } \\
\text { related problems }\end{array}$ & 24 & 90 & 26.67 \\
\hline $\begin{array}{l}\text { Decisions related } \\
\text { to routine } \\
\text { problems of } \\
\text { business }\end{array}$ & 55 & 90 & 61.11 \\
\hline $\begin{array}{l}\text { Marketing } \\
\text { oriented problems }\end{array}$ & 33 & 90 & 36.67 \\
\hline $\begin{array}{l}\text { Sales oriented } \\
\text { problems }\end{array}$ & 44 & 90 & 48.89 \\
\hline $\begin{array}{l}\text { Effective } \\
\text { Utilization of } \\
\text { business resources }\end{array}$ & 40 & 90 & 44.44 \\
\hline $\begin{array}{l}\text { Production } \\
\text { Oriented }\end{array}$ & 29 & 90 & 32.22 \\
\hline
\end{tabular}

\section{Source: Primary Data.}

Table 6.9 indicates that $\mathbf{2 8 8}$ responses were collected from 90 Animators. Out of 90 respondents, 61.11 per cent of them feel that members have taken decisions related to routine

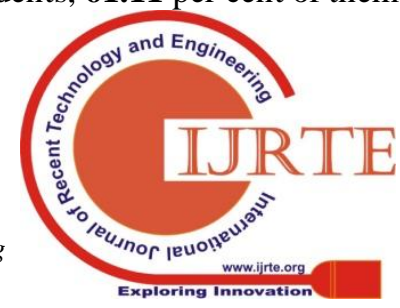


problems of business, $\mathbf{4 8 . 8 9}$ per cent of them have opined that members have given solutions related to sales oriented problems, followed by decisions taken by members for effective utilization of business resources opined by $\mathbf{4 4 . 4 4}$ per cent of Animators, $\mathbf{3 7 . 7 8}$ per cent of them told that financial related problems have tackled by members, 36.67 per cent opined that members found solutions to marketing oriented problems and so on.

It is clear that majority (61.11) of the members have given solutions to meet the day-to-day problems of business.

\subsubsection{LEVEL OF SELF CONFIDENCE POSSESSED BY MEMBERS}

The researcher has analyzed the level of Self Confidence possessed by members. Self Confidence is needed on the part of the women entrepreneurs to do the business activities and personal activities. Success or failures are the two coins of business and personal life. The researcher has identified 5 important situations at which the level of self confidence of members can be ascertained. Hence, this analysis is made and presented in Table 6.10.

TABLE 6.10

Level of Self-confidence Possessed by Members

\begin{tabular}{|l|l|l|}
\hline Possession of self confidence & Yes & No \\
\hline Facing and tacking the business & 62 & 43 \\
and social problems & $(59.05 \%)$ & $(40.95 \%)$ \\
\hline When they meet failure and loss & 82 & 23 \\
in business & $(78.10 \%)$ & $(21.90 \%)$ \\
\hline When they face business risks & 50 & 55 \\
and group risks & $(47.62 \%)$ & $(52.38 \%)$ \\
\hline While involving business and & 95 & 10 \\
group activities & $(\mathbf{9 0 . 4 8 \% )}$ & $(9.52 \%)$ \\
\hline When moving with the society & 70 & 35 \\
& $(66.67 \%)$ & $(33.33 \%)$ \\
\hline
\end{tabular}

\section{Source: Primary Data.}

Table 6.10 shows that the level of confidence at various situations. It indicates that $\mathbf{3 5 9}$ responses were collected from 105 Animators. Out of $\mathbf{1 0 5}$ Animators, $\mathbf{9 0 . 4 8}$ per cent of them have shared the opinion that their members have more confidence when they are involving business and Group activities, 78.10 per cent of them felt that the members have will power when they meet failure and loss in business, 66.67 per cent replied that their members are having confidence when they are moving with the society, $\mathbf{5 9 . 0 5}$ per cent of them opined that the members have confident in facing and tackling the business and social problems and the rest $\mathbf{4 7 . 6 2}$ per cent of them have expressed that their members have confident in facing business risks and group risks. It is clear that majority $(\mathbf{9 0 . 4 8 \%})$ of the members have been involving business and group activities.

\subsubsection{LEVEL OF SELF CONFIDENCE POSSESSED BY MEMBERS - SIGN TEST}

There is no significant difference between the responses of Animators towards the self confidence level of members at different situations. Testing the null hypothesis (Ho) of no difference using 5 per cent level of significance, the acceptance region will be $Z=-1.96$ to +1.96 . The results of Sign test are shown in Table 6.11.
TABLE 6.11

Result of Sign Test for Self-confidence Level of Members in SHGs

\begin{tabular}{|l|l|l|}
\hline Self Confidence Level & Z Value & Result \\
\hline $\begin{array}{l}\text { Facing and tacking the } \\
\text { business and social } \\
\text { problems }\end{array}$ & $1.86^{*}$ & $\begin{array}{l}\text { Not } \\
\text { Significant. }\end{array}$ \\
\hline $\begin{array}{l}\text { When they meet failure } \\
\text { and loss in business }\end{array}$ & $5.76^{*}$ & $\begin{array}{l}\text { Significant } \\
\text {. }\end{array}$ \\
\hline $\begin{array}{l}\text { When they face } \\
\text { business risks and } \\
\text { group risks }\end{array}$ & $-0.488^{*}$ & $\begin{array}{l}\text { Not } \\
\text { Significant. }\end{array}$ \\
\hline $\begin{array}{l}\text { While involving } \\
\text { business and group } \\
\text { activities }\end{array}$ & $8.30^{*}$ & $\begin{array}{l}\text { Significant } \\
\text { - }\end{array}$ \\
\hline $\begin{array}{l}\text { When moving with the } \\
\text { society }\end{array}$ & $3.42^{*}$ & $\begin{array}{l}\text { Significant } \\
\text {. }\end{array}$ \\
\hline Over all perception & $\mathbf{8 . 4 2 *}$ & $\begin{array}{l}\text { Significant } \\
\text {. }\end{array}$ \\
\hline
\end{tabular}

*Significant at 5 per cent level

Source: Compiled from Primary Data.

It is evident from the Table 6.11 that the $\mathrm{Z}$ value is within the acceptances region of null hypothesis $(Z=-1.96$ to +1.96 ) for statements number 1 , and 3 . This indicates there is no significant difference in the responses of Animators with regard to the self confidence level of members at these situations. For the other number of statements, the $\mathrm{Z}$ value is not within the acceptances region of null hypothesis. This indicates there is a significant difference in the responses of Animators with regard to the self confidence level of members at these situations. Hence, the null hypothesis is rejected. With regard to over all perception, it is concluded that there is a significance difference between the responses of the Animators towards self confidence level of members at various situations.

\subsubsection{OPINION ABOUT LEADERSHIP SKILLS OF MEMBERS}

The researcher has analyzed the leadership skills of members after joining SHG. Hence, this analysis is made and presented in Table 6.12

TABLE 6.12

Opinion about Leadership Skills of Members

\begin{tabular}{|c|c|c|}
\hline Leadership Skills & Yes & No \\
\hline $\begin{array}{l}\text { Ability of directing the } \\
\text { others }\end{array}$ & $\begin{array}{l}74 \\
(70.48 \%)\end{array}$ & $31(29.52 \%)$ \\
\hline $\begin{array}{l}\text { Get the work done } \\
\text { through others }\end{array}$ & $\begin{array}{c}105 \\
(\mathbf{1 0 0 \%}) \\
\end{array}$ & $0(0 \%)$ \\
\hline $\begin{array}{l}\text { Attract others by } \\
\text { influencing their activities }\end{array}$ & $\begin{array}{l}47 \\
(44.76 \%) \\
\end{array}$ & $\begin{array}{l}58 \\
(55.24 \%) \\
\end{array}$ \\
\hline Attract to protect others & $\begin{array}{l}42 \\
(40.00 \%)\end{array}$ & $\begin{array}{l}63 \\
(60.00 \%) \\
\end{array}$ \\
\hline $\begin{array}{l}\text { Ability to give valuable } \\
\text { suggestions and ideas to } \\
\text { lead and improve the } \\
\text { group and business } \\
\text { activities }\end{array}$ & $\begin{array}{l}57 \\
(54.29 \%)\end{array}$ & $\begin{array}{l}48 \\
(45.71 \%)\end{array}$ \\
\hline
\end{tabular}




\section{Women Entrepreneurial Skills of Self Help Groups for Sustainable Development in Tirunelveli District}

\begin{tabular}{|l|l|c|}
\hline $\begin{array}{l}\text { Win the confidence of } \\
\text { others }\end{array}$ & $\begin{array}{l}36 \\
(34.29 \%)\end{array}$ & $\begin{array}{l}69 \\
(65.71 \%)\end{array}$ \\
\hline
\end{tabular}

Source: Primary Data.

It is exhibited from Table 6.12 that out of 105 Animators, 100 per cent of them replied that their members are able to get the work done through others, $\mathbf{7 0 . 4 8}$ per cent of them have opined that their group members are having ability to direct others, 54.29 per cent of them opined that members are having ability to give valuable suggestions and ideas to improve group as well as business activities, $\mathbf{4 4 . 7 6}$ per cent answered that their members have attracted others by influencing their activities, $\mathbf{4 0 . 0 0}$ per cent of them feel that members are able to protect others and the remaining $\mathbf{3 4 . 2 9}$ per cent of them opined that members are having confidence to win the confidence of others. It is clear that all members are having ability to get the work done through others.

\subsubsection{OPINION ABOUT LEADERSHIP SKILLS OF MEMBERS - SIGN TEST}

In order to test the null hypothesis that there is no significant difference between the responses of Animators towards leadership skills level of members, the Sign test has been used and the results obtained are presented in Table 6.13 .

TABLE 6.13

Leadership Skills Level of members in SHGs

\begin{tabular}{|c|c|c|}
\hline Leadership Skills & Z Value & Result \\
\hline Ability of directing the others & $4.20 *$ & Significant \\
\hline $\begin{array}{l}\text { Get the work done through } \\
\text { others }\end{array}$ & $10.25^{*}$ & Significant \\
\hline $\begin{array}{l}\text { Attract others by influencing } \\
\text { their activities }\end{array}$ & $-0.29 *$ & $\begin{array}{l}\text { Not } \\
\text { Significant }\end{array}$ \\
\hline Ability to protect others & $-1.86^{*}$ & $\begin{array}{l}\text { Not } \\
\text { Significant }\end{array}$ \\
\hline $\begin{array}{l}\text { Ability to give valuable } \\
\text { suggestions and ideas to lead } \\
\text { and improve the group and } \\
\text { business activities }\end{array}$ & $0.88 *$ & $\begin{array}{l}\text { Not } \\
\text { Significant }\end{array}$ \\
\hline Win the confidence of others & $-3.22 *$ & Significant \\
\hline Over all perception & 4.06* & Significant \\
\hline
\end{tabular}

*Significant at 5 per cent level

Source: Compiled from Primary Data.

It is evident from the Table 6.13 that the $Z$ value is within the acceptance region of null hypothesis $(Z=-1.96$ to +1.96$)$ for statements number 3,4 and 5 . Therefore, there is no significant difference in the responses of Animators and the leadership skills for the above statements. For the other statements, the $\mathrm{Z}$ value is not within the acceptance region of null hypothesis. Hence, there is a significant difference in the responses of Animators towards statements of leadership skill number 1, 2 and 6.The calculated value of ' $Z$ ' for the leadership skills level of members is not within acceptance region. Hence, the null hypothesis is rejected. With regard to over all perception, it is concluded that there is a significance difference between the responses of Animators towards leadership skills level of members.

\section{SUGGESTIONS TO THE STUDY}

* Majority of the Animators of SHGs have felt that the members have not given innovative ideas to the business. Therefore, the authorities of the Mahalir Thittam should concentrate on various research programmes about business, product, market, customer and technology. The members should be allowed to participate in it. Thereby they can develop innovativeness skill. Hence, more number of training programmes should be conducted to develop the innovative skills of the members.

* More than $50 \%$ of the Animators have felt that the members have not contributed in planning activities. The authorities may make a strict rule that all the members should take active part in planning activities of the Group as well as business activities. If any member is not taking participation continuously in planning activities, she will be deprived of benefits of SHGs. Some awareness and motivational programmes should be given to the members about the importance and benefits of planning activities. The members who have contributed in planning activities should be appreciated and recognized in front of others.

* Majority of the Animators have felt that the members are not ready to face the risks involved in business because of fear about loss. The concerned authorities should give awareness and motivational programmes about how to face the risks by having safety measures against them, arrange infrastructure facilities, and educate the members to understand the various types of risks and ways and means to tackle them.

\section{CONCLUSION}

The Animators are playing a vital role in molding the overall performance of the members particularly related to entrepreneurial activities. Now a days women are facing more challenges and problems related to business. Even though there are many problems, the self confidence level of members is high when they are doing group and business activities. Animators should motivate the members to develop and update their knowledge recent trends, in Technology, Marketing, sources and effective utilization of investment related to their business. If the above suggestions are implemented by the Government and the officials of the Mahalir Thittam, they would be able to do the business and Group activities without any difficulties. Hence, the present study is much needed for developing their skills which will lead to be successful entrepreneur.

\section{REFERENCES}

1. Praveen Kumar (2015), "Women empowerment through entrepreneurship", International Journal of Applied Science \&Technology Research Excellence Vol .5 Issue 5, Nov.-Dec. 2015, ISSN NO. 2250-2718(Print),p. 43-46

2. Kumar, p., (2015), " A study on Women Entrepreneurs in India", International Journal of Applied Science \& Technology Research Excellence Vol. 5, Issue 5, pp 43-46

3. Kavita Sangolagi1, Mallikarjun Alagawadi (2016). "Women Entrepreneurs" International Journal of advancement in engineering technology, Management \& applied science, 3 (2), 222-91.

4. Neha Tiwari (2017), Women Entrepreneurs in India: A literature review, Amity Journal of Entrepreneurship, 2(1), 47-60

5. Rajeswari, M. and Sumangla, P.,Women Entrepreneurs- A Scene on their Problem and Prospectus, Kanishka Publishers, New Delhi 1995, P.29.

6. Nandapurkar, G.G., Small Farmers, A Study on their Entrepreneurial Behaviour

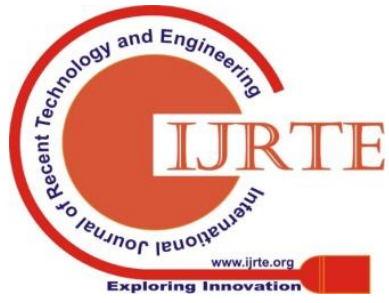


Metropolitan Book Company Limited, New Delhi, 1982.

7. Raja Gopal, M., Rural Market and Entrepreneurship, Rewat Publications, New Delhi, 1989.

8. Soundarapandian, (ed.,) Women Entrepreneurship - Issues and Strategies, Kanishka Publications, New Delhi, 1999.

9. Desai, Vasanth, Dynamics of Entrepreneurial Development and Management, Himalaya Publishing House, Mumbai, 1992.

\section{AUTHORS PROFILE}

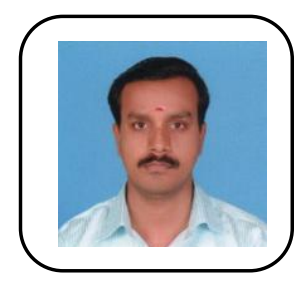

Dr.R.Selvakumar has completed M.Com., MPhil. Ph.D SET., PGDCA.,. He has presented 57 papers in National and International level. He has published 41 Articles in International and National Journals including Scopus indexed Journals. He has guided M.com projects. He received Life time Member in Teaching and Education Research Association (TERA), Social Science and Humanities Research Association (SSHRA) and IRDP group of journals. He has also received two awards Teaching Excellence award 2018 and Teaching and Research Excellence award 2019.

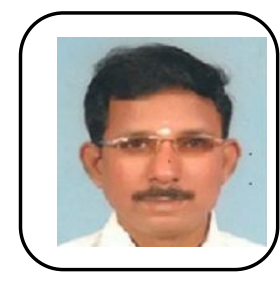

Dr.S.Karthik has completed M.Com., MPhil., Ph.D SET., PGDCA.,MBA . He has presented 54 papers in National and International level. He has published 26 Articles in International and National Journals including Scopus indexed Journals. He has guided M.com projects and Ph.D project. He received Life time Member in Teaching and Education Research Association (TERA), Social Science and Humanities Research Association (SSHRA) and IRDP group of journals. He has also received three awards Best Teacher award 2013, Teaching Excellence award 2018 and Life time Teaching and Research Excellence award 2019 